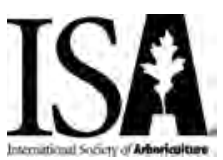

Arboriculture \& Urban Forestry 2016. 42(5): 285-300

\title{
Homebuilder Practices and Perceptions of Con- struction on the Wooded Lot: A Quarter Century Later Follow-Up Assessment
}

\author{
Keith O’Herrin, Richard J. Hauer, William J. Vander Weit, and Robert W. Miller
}

\begin{abstract}
Building new homes on wooded lots is common in the upper Midwest, United States. Existing trees are often left behind during construction to become part of the future landscape. A study conducted in 1980 found that homebuilders in Portage County, Wisconsin, U.S. generally had a poor understanding of how construction activities could impact the health of trees intended to be preserved. Researchers replicated that study 27 years later by surveying homebuilders in the same region to see how their tree preservation knowledge and use of construction activities have changed during that time. The results indicate few construction activities changed significantly, showing that little has changed overall to improve tree preservation. Even though builders significantly improved their knowledge of the negative effects that storage of fill soil on roots poses to tree preservation, they also significantly increased usage of that very same activity. Builders almost never consulted a tree preservation expert and thought doing so was the least important activity when making tree preservation decisions. Interest in a tree preservation training workshop was limited. Unless pressured by consumer demand or regulation, builders will probably not improve their tree preservation knowledge, change their construction activities, or include tree experts anywhere in the process.

Key Words. Construction; Damage; Followup; Home Builders; Landscape; Perceptions; Public; Tree Experts.
\end{abstract}

Over the last 30 to 40 years, new home construction within woodlots and forests has been a common practice within the United States (Matheny and Clark 1998; Johnson 1999; Fite and Smiley 2008b; Haines et al. 2011). Several factors explain this, including a society that has moved away from filling in wetlands, parcelization of larger into smaller lots through subdivision, and people's preference for living within a forest (Hoff 1999; Haines et al. 2011; Haines and McFarlane 2012). People throughout the world have a desire to build homes in wooded environments, which sometimes causes conflict, such as competition for space between existing trees and new construction when converting land from a forested to a developed environment (O'Callaghan and Lawson 1995; Konijnendijk 2008; Miller et al. 2015). Developers and builders have responded to this desire by selecting forested sites for new home construction.

In some cases, developers remove existing vegetation and create an untreed lot. In other cases, when designing and planning the new home, it has become customary to leave forest trees to become part of the new landscape. If proper caution or care is not provided for these residual trees during development and construction, they may become very expensive liabilities as declining and dead trees near homes within a few years (Anderson and BarrowsBroaddus 1989; Day and Bassuk 1994; Hauer et al. 1994; Gilbert 1996; Koeser et al. 2013; Miller et al. 2015). During home construction, the damages to trees may include soil compaction, grade change, mechanical injury, root damage, improper pruning, and chemical changes in the soil due to spills or storage (Johnson 1999; Day et al. 2010a; Day et al. 2010b; Watson et al. 2014a). These potential damages to trees are all avoidable if proper planning, design, and implementation occur (Johnson 1999; Galvin et al. 2000; Harris et al. 2004; Fite and Smiley 2008b; Fite and Smiley 2009; Watson et al. 2014a).

Compounding this issue of damage during construction is the tendency for developers to harvest the best trees from the property for their timber value, rather than leaving areas of continuous or remnant forest intact (Harris et al. 2004; Miller 
et al. 2015). This practice of high grading the site before subdivision into lots can result in trees with poor structure or health remaining as part of the future landscape because the same defects that can preclude trees from being harvested can make them unfit to be preserved for the built environment (Harris et al. 2004; Fite and Smiley 2008a). These trees may have insect, disease, or structural problems, which when combined with the stress induced by nearby construction activities, result in a negative tree preservation outcome (Matheny and Clark 1998; Johnson 1999; Harris et al. 2004; Fite and Smiley 2008b). Homeowners and builders who lack skills to properly develop and implement plans, and to supervise the preservation of trees, often leave behind trees that should not be saved, or unknowingly injure trees in the construction process (Johnson 1999; Fite and Smiley 2008b).

Builders' land development practices are typically motivated by profit and market demand (Vigmostad 2003; Tinker et al. 2006). When building homes on speculation, a builder often selects conventional land development models even if an unconventional practice (e.g., tree preservation) may be more profitable. This is known as satisficing (Bowman and Thompson 2009; Westbrook 2010). However, if homebuyers educate themselves on alternatives to conventional land development models and request a given feature, builders would probably respond if the market demanded it (Vigmostad 2003; Ryan 2006).

Reputation and public image are very important to developers. They take large financial risks when developing large subdivisions, and so they frequently respond to market demand (Sevelka 2004; Ryan 2006; Bowman and Thompson 2009; Westbrook 2010). This can be seen with the improvement of energy efficiency of new homes over the last 20 to 30 years, from windows and walls to appliances. As requests from educated consumers for energy efficiency have increased, builders have acquired the necessary training, and these features have become conventional.

In central Wisconsin, U.S., prospective homeowners have historically relied exclusively on a building contractor to plan and create their new home, rather than including professionals trained in tree preservation on construction sites (Vander Weit and Miller 1986). During the past quarter century, many important practices have been developed that minimize damage to trees during construction (Matheny and Clark 1998; Johnson 1999; Harris et al. 2004; Fite and Smiley 2008a; Fite and Smiley 2008b; Fite and Smiley 2009; Watson et al. 2014b). Professional arborists and urban foresters trained in these methods can provide tree preservation plans that are effective if followed from the outset of development to completion.

In the past, builders in central Wisconsin did not routinely consult with tree preservation professionals (Vander Weit and Miller 1986). Therefore, the success of tree preservation during construction depended on builder knowledge and activities. In 1980, builder knowledge of the negative impacts on trees incurred during construction was generally poor (Vander Weit 1984; Vander Weit and Miller 1986). As with tree preservation plans developed by professional arborists and urban foresters, the use of proper best management practices by builders during home construction can be critical to the successful preservation of trees and are most effective when followed from start to finish (Fite and Smiley 2008a). The objective of this study was to determine the perceptions and knowledge of central Wisconsin builders and developers regarding trees and construction activity, and how those perceptions and knowledge have changed since 1980.

\section{METHODS}

The study of builder perceptions, activities, and knowledge of construction in wooded lots was conducted in Portage County, Wisconsin, U.S. This central Wisconsin location covers $2,074 \mathrm{~km}^{2}$ with a population of 70,019 people (U.S. Census Bureau 2010). Population growth was $0.73 \%$ annually over the past 30 years. Builders selected for the study were members of the Golden Sands Home Builders Association (GSHBA); researchers targeted $100 \%$ of this builder group $(n=49)$. Tree preservation regulations and ordinances are non-existent in the study area (Ernster 2015). An exception would be any covenants that a subdivision may have placed upon itself through this regulatory approach that may stipulate tree preservation and/or construction near trees.

A questionnaire, approved by the UWSP Human Subjects committee, consisted of 42 questions, 28 of which were adapted from a previous study administered in 1980 by Vander Weit (1984) 
and Vander Weit and Miller (1986). That study was designed to examine typical building practices and the level of knowledge of homebuilders regarding the preservation of trees during new home construction on a wooded lot. This study was designed as a followup to quantify any changes that occurred between 1980 and 2008. Questions were designed around activities that typify building homes in wooded lots, builders' perceptions of homeowners' desires on what types of trees to retain and conversion of wooded lots to a built environment, builder knowledge of soils and general arboricultural practices, and the importance of activities commonly used in tree preservation projects. An additional 14 questions were designed to supplement the previous questionnaire with updated arboricultural information and techniques, regularity of construction in wooded environments, root pruning, and tree root structure. The unimportance to importance of tree preservation activities were ascertained through a five-point Likert scale $(1=$ Very Unimportant, 2 = Unimportant, $3=$ Neutral, $4=$ Important, and $5=$ Very Important). Further questions were designed to determine the level of interest held by respondents in attending a workshop for homebuilders regarding the preservation of trees during new home construction on wooded lots, as well as the preferences expressed to builders by homeowners regarding trees on the wooded lot. The table and figure titles and descriptions were developed from the wording as presented in the research questionnaire.

A questionnaire was sent by postage mail in early spring of 2008 to a list of 49 homebuilders in the central Wisconsin region, following Dillman's (2007) method. All questionnaires contained a unique identifier to track which homebuilders had responded and to target reminder postcards and duplicate questionnaires accordingly. The first mailed item was a letter informing the homebuilder they could expect to receive a questionnaire in the mail soon. The second mailed item was a packet containing a cover letter explaining the research study, the questionnaire itself, and a self-addressed and postage-paid envelope for returning the questionnaire. The third mailed item was a postcard reminding any non-responding homebuilder they had received the questionnaire in the mail and requesting the homebuilder con- tact the researchers if they required a replacement questionnaire. The fourth mailed item, as necessary, was a replacement questionnaire to homebuilders who had not yet responded.

A total 27 homebuilders responded to the survey of 49 total sent, for a 55\% response rate. The respondents spent an average of 18.6 minutes completing this survey, with no one devoting less than 10 minutes or more than 40 minutes to complete a four-page questionnaire. The 1980 study by Vander Weit and Miller (1986) had 15 of 22 homebuilders respond (68\%).

Frequency counts and means were used as appropriate to describe study results. Differences in responses between 1980 and 2008 were evaluated using a test comparing two binomial proportions for builder site characterization, knowledge, and activity questions using VassarStats (Ott and Longnecker 2010; Lowery 2015). Testing for a difference in knowledge of species tolerance and longevity used a Fisher's Exact Test for a $2 \times 2$ contingency (GraphPad 2015). Significance for all tests, except where noted, was set at an $\alpha \leq 0.05$ significance level as evidence to reject a null hypothesis of no differences between both study periods. Marginal significance was interpreted for probabilities between an $\alpha>0.05$ and $\leq 0.10$.

\section{RESULTS}

This study found a variety of changes and similarities between past and more recent activities and perceptions of builders and homeowners regarding construction within wooded lots. The study population of builders frequently (41\%) or occasionally (59\%) built in wooded lots, with no builders never or rarely constructing in this environment. During development a mean 44\% of trees were removed from a lot (Figure 1).

Buyer and builder preferences for tree removal by type or size and lot appearance after construction were unchanged from 1980. Most builders (78\%) give no preference to the size of tree removed (Table 1). This was not significantly different from the $81 \%$ reporting such in 1980 . Builders that do preferentially select trees tend to leave larger trees, with only $33 \%$ removing trees larger than $25 \mathrm{~cm}$. All said they removed small trees between 5.0 to $9.9 \mathrm{~cm}$, and $83 \%$ removed medium-sized trees 
between 10 to $25 \mathrm{~cm}$. Builders were less likely to preferentially remove certain types of tree species. A total $74 \%$ indicated species type was unimportant with removal decisions, and this finding was similar to the 1980 reporting of $81 \%$. Jack pine (Pinus banksiana Lamb.), pine (Pinus spp.), and conifer were indicated as species selectively removed.

Homebuyers, in contrast to builders, have a preference for retaining trees with certain size and species attributes, as reported by the builders (Table 1). Builders indicated that over $40 \%$ of buyers have a preference for the size of trees retained. Large trees are the most desired by over $70 \%$ of homebuyers who have a preference for tree size. No

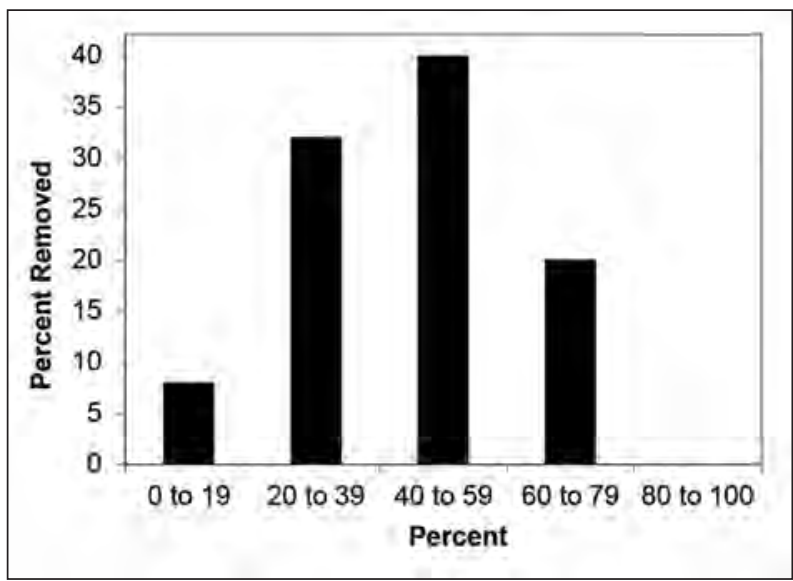

Figure 1. The percent removal of trees by homebuilders during construction of wooded lots in central Wisconsin, U.S. by percentage removed category (mean $44 \%$ removed). preference was given for small trees. Size and species findings were consistent and statistically similar with those from 1980. Homebuyers' preference for the site after development was also similar to 1980 findings. Over $80 \%$ desired a partially landscaped and partially natural lot. Approximately $15 \%$ desired the site left as natural as possible, and less than 5\% wanted the lot totally landscaped. Buyers also preferred certain species with 67\% expressing preference of the tree type retained.

Home locations on the building site were seldom $(59 \%)$ or never (4\%) moved to avoid tree damage. Only $37 \%$ of builders said the house footprint was moved to avoid tree damage. Tree damage was a complaint builders received, however, $63 \%$ said no complaints from homebuyers were received at all. Buyers did complain to builders about dead trees (26\%), portions of trees dying $(22 \%)$, scars on trees (19\%), and exposed roots (19\%). After development, $65 \%$ of the wood was removed from the site, 19\% was left on-site, and $8 \%$ each said wood was either burned or sold.

\section{Builders' Activities on Wooded Lots}

Home construction activities reported by builders included excavation for the home and utilities, placement of driveways and walkways, changes to grade, soil movement and stockpiling, and heavy equipment use on-site. Many activities had similar rates of occurrence between the results

Table 1. Characterization of development of woodlots into residential lots in central Wisconsin and buyer preferences in $1980(n=16)$ and $2008(n=27)$.

\begin{tabular}{|c|c|c|c|c|c|}
\hline \multirow[b]{2}{*}{ Buyer site preferences } & \multicolumn{5}{|c|}{ Percent yes } \\
\hline & 1980 & 2008 & Relative change & Z-score & $P$-value \\
\hline Are certain sized trees removed? & 18.7 & 22.2 & 3.5 & -0.271 & 0.7864 \\
\hline If yes, small size 5.0 to $9.9 \mathrm{~cm}$ & NA & 100.0 & & & \\
\hline If yes, medium size 10 to $25 \mathrm{~cm}$ & NA & 83.3 & & & \\
\hline If yes, large size $>25 \mathrm{~cm}$ & NA & 33.3 & & & \\
\hline Are certain types of species removed? & 18.7 & 25.9 & 7.2 & 0.432 & 0.666 \\
\hline Buyers express preference for type (species) left on lot & 81.3 & 66.7 & -14.6 & 0.917 & 0.359 \\
\hline Buyers express preference for certain tree size left on lot & 56.3 & 40.7 & -15.6 & -0.372 & 0.710 \\
\hline If yes, small size 5.0 to $9.9 \mathrm{~cm}$ & 0.0 & 0.0 & 0.0 & 0.000 & 1.000 \\
\hline If yes, medium size 10 to $25 \mathrm{~cm}$ & 30.0 & 27.3 & -2.7 & 0.222 & 0.824 \\
\hline If yes, large size $>25 \mathrm{~cm}$ & 70.0 & 72.7 & 2.7 & -0.222 & 0.824 \\
\hline \multicolumn{6}{|l|}{ Buyers preference for site following development: } \\
\hline Site left as much as much as possible as native & 12.5 & 14.8 & 2.3 & -0.131 & 0.895 \\
\hline A partially landscaped and partially natural site & 81.3 & 81.5 & 0.2 & -0.117 & 0.907 \\
\hline A totally landscaped lot & 6.3 & 3.7 & -2.6 & 0.432 & 0.666 \\
\hline
\end{tabular}

Significant at $P \leq 0.05$ level.

Note: NA = Not applicable, as the question was not asked in 1980. 
Table 2. Percentage of builders in central Wisconsin who build in wooded lots and indicated the following questions typify their activities when building residential homes on wooded lots in $1980(n=16)$ and $2008(n=27)$.

\begin{tabular}{|c|c|c|c|c|c|}
\hline \multirow[b]{2}{*}{ Activity area } & \multicolumn{5}{|c|}{ Percent yes } \\
\hline & 1980 & 2008 & Relative change & Z-score & $P$-value \\
\hline Foundations placed within 0 to $3 \mathrm{~m}$ of trees & 62.5 & 7.4 & $-55.1^{z}$ & 3.893 & $<0.0002$ \\
\hline Driveways placed within 0 to $3 \mathrm{~m}$ of trees & 87.5 & 63.0 & $-24.5^{y}$ & 1.734 & 0.083 \\
\hline Heavy equipment passing near base of tree & 81.3 & 70.4 & -10.9 & 0.790 & 0.430 \\
\hline Trees removed & 93.8 & 92.6 & -1.2 & 0.144 & 0.886 \\
\hline Trenching for underground utilities & 93.8 & 96.3 & 2.5 & -0.383 & 0.702 \\
\hline Sidewalks placed within 0 to $3 \mathrm{~m}$ of trees & 56.3 & 59.3 & 3.0 & -0.193 & 0.847 \\
\hline Trees pruned & 56.3 & 59.3 & 3.0 & -0.193 & 0.847 \\
\hline Trees or shrubs planted & 37.5 & 40.7 & 3.2 & -0.210 & 0.834 \\
\hline Storage of building materials around the base of trees & 50.0 & 55.6 & 5.6 & -0.353 & 0.724 \\
\hline Lowering of the grade & 25.0 & 40.7 & 15.7 & -1.047 & 0.295 \\
\hline Raising of grade (fill) & 62.5 & 92.6 & $30.1^{z}$ & -2.451 & 0.014 \\
\hline Temporary soil storage around the base of trees & 43.8 & 77.8 & $34.0^{z}$ & -2.263 & 0.024 \\
\hline Paint wounds on oaks immediately after wounding & NA & 40.7 & NA & NA & NA \\
\hline Providing irrigation for trees as needed & NA & 18.5 & NA & NA & NA \\
\hline Placement of tree protection fencing under the drip line & NA & 11.1 & NA & NA & NA \\
\hline Root pruning prior to construction & NA & 7.4 & NA & NA & NA \\
\hline
\end{tabular}

from 1980 and the more recent study period (Table 2). Trees were regularly removed (over 90\%) and pruned (nearly 60\%) by builders. Trees and shrubs were also planted by approximately $40 \%$ of builders in both time periods.

Excavation near trees was examined. Very few builders (7\%) in 2008 reported placing foundations within $3 \mathrm{~m}$ of trees. This was lower $(P<0.0002)$ than in 1980 when over $60 \%$ did such. The percentage of builders reporting that they place driveways within $3 \mathrm{~m}$ of trees decreased $(P=0.083)$ and most recently was $63 \%$ compared to $87 \%$ in 1980 . Sidewalk placement within $3 \mathrm{~m}$ was practiced by $59 \%$ of builders, which was similar to the $56 \%$ in 1980. Trenching for underground utilities was unchanged and also commonly done by approximately $95 \%$ of builders in both time periods.

Soil movement and grade changes were reported to occur commonly. Raising soil grades significantly increased $(P=0.014)$ from $63 \%$ of builders reporting such in 1980 to $93 \%$ doing such in 2008 (Table 2). Soil grades are also lowered by approximately $40 \%$ of builders. Soil was also stored near the base of trees by $78 \%$ of builders, which was significantly greater $(P=0.014)$ than the $44 \%$ in the 1980 results. In addition to soil storage, building materials were stored near the base of trees with over $56 \%$ reporting such in 2008 . This was consistent, with $50 \%$ of respondents storing materials there in 1980. The use of heavy equipment passing near a tree base was still commonly occurring, as reported by over $70 \%$ of builders. Only three builders either regularly $(4 \%)$ or occasionally (15\%) used mulch or placed boards prior to driving over root systems to prevent soil compaction. In contrast, the vast majority either rarely (33\%) or never $(48 \%)$ did such to prevent damage to tree roots and soil.

Overall, builders infrequently or rarely engaged in four activities useful to foster tree health (not included in 1980 questionnaire). Only 41\% indicated they paint wounds on oaks following wounding as a prevention treatment for oak wilt [Ceratocystis fagacearum (T.W. Bretz) J. Hunt] even though the disease commonly occurs in the study area. Few used irrigation as needed (19\%) to maintain a desired soil moisture level. The placement of tree protection fencing under the drip line was uncommon and used by $11 \%$ of builders. Finally, root pruning in advance of excavation was reported by only $7 \%$ of builders.

\section{Builders' Knowledge of Activities and Arboriculture}

Several questions were used to determine builder knowledge of arboriculture and how this affects trees and the environment (Table 3). Overall builder knowledge did not statistically rise from $51 \%$ answering each of 16 questions correctly in 1980 compared to $57 \%$ in 2008 . However, there was a statistical increase in knowledge found with 
6 of 16 questions. Soil questions examined knowledge concerning soil compaction, soil texture, water movement, soil fill, and cement wastewater impacts. Questions concerning pruning practices asked where branch pruning should occur, knowledge on pruning paint, and compensatory pruning for root loss. Understory questions examined knowledge about grass competition, mulch, and native undergrowth vegetation. Few builders (22\%) use consulting foresters, arborists, or other tree experts to create development plans, with $78 \%$ saying they did not use external expertise.

\section{Soils}

Overall, builders scored very highly on questions relating to soils knowledge (Table 3). A total 100\% of respondents knew that soil compaction becomes most severe when the soil was wet, which was higher $(P=0.060)$ than $87.5 \%$ from 1980 . All respondents were able to correctly arrange three soil textures according to air and water movement through the soil, and most (94\%) knew this in 1980. Those knowing the effect of cement wastewater on soil $\mathrm{pH}$ was $93 \%$, and statistically no change $(P=0.108)$ was detected from $75 \%$ saying such in 1980 . However, most respondents were still unable to arrange three soil textures according to the degree of predisposition to compaction, with only $22 \%$ correctly answering, which was unchanged from 19\% in 1980.

\section{Pruning}

Respondents were asked to describe pruning practices (Table 3). In 1980, the majority (56\%) indicated they cut branches flush to the trunk, while only $21 \%(P=0.032)$ did such in this study. Flush-cut pruning was considered the correct practice in the initial 1980 study. Two options were added to this question ('prune at the branch collar' and 'where pruned is not important') in the recent study. In the recent study, pruning to the branch collar had the highest response (37\%), followed by don't know (30\%). Most respondents (74\%) thought pruning paint prevents decay. Few (11\%) knew wound painting is cosmetic only and $11 \%$ did not know.

\section{Tree-understory relationships}

Builders were asked about how trees in wooded lots contribute to an ecosystem of canopy, understory, and belowground functions (Table 3). Similar to $1980,50 \%$ of respondents answered that grass around the base of the tree is beneficial. Also similar to 1980 results, respondents expressed grass has no effect (23\%) or is detrimental $(27 \%)$ to tree health. A majority (62\%) of respondents in both study periods similarly indicated that mulch around the base of a tree is preferable to grass. Only $37 \%$ answered that removal of native undergrowth vegetation and leaf litter will generally be detrimental to a tree, while $30 \%$ answered

Table 3. Percent of builders responding correctly to questions of arboricultural knowledge and effects of construction activities on the development site in $1980(n=16)$ and $2008(n=19$ to 27$)$.

\begin{tabular}{|c|c|c|c|c|c|}
\hline \multirow[b]{2}{*}{ Knowledge area } & \multicolumn{5}{|c|}{ Percent correct } \\
\hline & 1980 & 2008 & Relative change & Z-score & $P$-value \\
\hline Heavy equipment will injure exposed and underground roots & 50.0 & 92.6 & $42.6^{\mathrm{z}}$ & -3.196 & 0.001 \\
\hline Correct identification of tree longevity of selected species & 48.4 & 72.5 & $24.1^{\mathrm{z}}$ & -6.129 & $<0.0002$ \\
\hline Fill over existing soil level will hinder air and water exchange & 75.0 & 96.3 & $21.3^{\mathrm{z}}$ & -2.106 & 0.035 \\
\hline Correct identification of shade tolerance of selected species & 34.6 & 53.5 & $18.9^{\mathrm{z}}$ & -4.509 & $<0.0002$ \\
\hline Cement wastewater can increase soil alkalinity & 75.0 & 92.6 & 17.6 & -0.161 & 0.108 \\
\hline Compaction is most severe when the soil is wet & 87.5 & 100.0 & $12.5^{y}$ & -1.881 & 0.060 \\
\hline Application of fertilizer after root damage & 6.3 & 16.0 & 9.7 & -0.931 & 0.352 \\
\hline Proper arrangement of soil texture considering air and water movement & 93.8 & 100.0 & 6.2 & -1.125 & 0.224 \\
\hline Grass around the base of trees can be detrimental & 18.8 & 23.1 & 4.3 & -0.332 & 0.740 \\
\hline Proper arrangement of soil texture and compaction & 18.8 & 21.7 & 2.9 & -0.271 & 0.786 \\
\hline Lateral extent of tree roots & 81.3 & 82.6 & 1.3 & -0.109 & 0.913 \\
\hline Effect of mulch on trees is preferred to grass & 62.5 & 61.5 & -1.0 & 0.062 & 0.951 \\
\hline Pruning paint is mainly cosmetic and doesn't prevent decay & 18.8 & 11.1 & -7.7 & 0.699 & 0.485 \\
\hline Native undergrowth and leaf litter removal will benefit the tree & 43.8 & 29.6 & -14.2 & 0.939 & 0.348 \\
\hline Wise to prune a portion of branches to compensate for root loss & 50.0 & 30.8 & -19.2 & 1.246 & 0.213 \\
\hline When pruning it is best to cut flush with the trunk or branch ${ }^{\mathrm{x}}$ & 56.3 & 21.1 & $-35.2^{\mathrm{z}}$ & 2.247 & 0.032 \\
\hline Overall & 51.3 & 56.6 & 5.3 & 0.008 & 0.994 \\
\hline
\end{tabular}

${ }^{\mathrm{z}}$ Significant at $P \leq 0.05$ level.

y Significant at $P \leq 0.10$ level.

${ }^{x}$ Flush-cut pruning was considered the correct response in the 1980 study. 
that removal would actually benefit the tree, and $33 \%$ believed it will have no effect on the tree.

\section{Roots and root damage}

Almost all builders (96\%) answered that fill over existing soil levels will hinder the exchange of water and air between tree roots and soil (Table 3 ). This was significantly greater $(P=0.035)$ than the $75 \%$ who answered such in 1980 . Only $4 \%$ (one builder) answered that fill has no effect. No builders believed that adding fill would improve exchange, as $19 \%$ of respondents did in 1980. Knowledge about heavy equipment passing near trees injuring exposed roots as well as underground roots increased significantly ( $P=0.001$ ) from $50 \%$ in 1980 to $93 \%$ in the recent study. Builders gave a range of $10 \%$ to $55 \%$ of the root system that can be removed before death is likely with a mean $25.7 \%$ root removal resulting from the question. The majority (81\%) of builders wrote in a number equal to or less than $33 \%$ when asked what percent of the tree root system can be removed before the death of the tree is likely. This question was not asked in 1980.

Builder perception of root system structure was unchanged from 1980, with $70 \%$ believing roots only extend to approximately the canopy edge. Only $13 \%$ of builders knew that tree roots generally extend away laterally from the tree trunk a distance two times or more the distance from the trunk to the canopy edge. Seventeen percent of respondents thought roots only extend halfway from the trunk to the canopy edge. In response to the depth of tree root systems, only $40 \%$ believed roots are most prevalent in the upper 50 to $100 \mathrm{~cm}$ of the soil. No builders thought roots went as deep as the tree is tall, $4 \%$ thought half as deep as tall, and the majority (56\%) thought tree roots go approximately one quarter deep as the tree is tall.

Insight was gained into activities taken to compensate for root damage. A total $31 \%$ of builders said they prune trees to compensate for root loss, which was statistically similar to the $50 \%$ doing such in 1980. Knowledge of the impact of fertilizer was ascertained, with $48 \%$ saying application of nitrogen was helpful to trees recovering from root damage. This was significantly lower $(P=0.010)$ than the $88 \%$ who said such about nitrogen in 1980. Adding phosphorus was indicated by $16 \%$, and potassium by $36 \%$ of respondents.

\section{Longevity and shade tolerance}

Builders' knowledge of individual tree species improved from 1980 to 2008. Builders as a whole correctly answered $72 \%$ of questions relating to longevity of individual tree species, which was significantly higher $(P<0.0002)$ than $48 \%$ correctly answering in 1980 (Table 4). Builders' knowledge of the shade tolerance of individual tree species significantly increased $(P<0.0002)$, as they correctly answered $54 \%$ of the questions compared to 35\% correct in 1980 (Table 5).

\section{Interest in continuing education}

The majority of builders did not know if they wanted to attend (41\%) or were not interested $(22 \%)$ in attending a workshop regarding building in wooded lots and tree preservation. Respondents with interest or unsure about attending were most interested in a two-hour $(45 \%)$ or four-hour (45\%) workshop. Many (35\%) would not pay to attend a workshop, and those that that would pay were willing to pay a mean USD $\$ 34$ for continuing education on trees and building in wooded lots.

\section{Importance of Tree Preservation Activities}

The development of tree preservation plans and site assessment of trees (e.g., tree risk assessment, tree condition rating, species, size) before and during construction was ascertained. This information, along with the planning and modification of construction activities, is vital to minimizing construction damage to existing trees. Builder response varied on the importance of tree preservation activities from a low index score of 2.58 ( 1 = Very Unimportant to 5 = Very Important) for consulting with tree professionals to a high 4.19 of identification of tree location in proximity to construction activities (Figure 2). Avoiding excessive fill (4.04), assessment of tree condition (3.85), determining tree suitability for preservation (3.69), identification of vehicle access movement (3.56), and avoiding trenching near the tree base (3.56) were also considered relatively 
Table 4. Percent of builders rating a tree species as either short-lived (SL) or long-lived (LL) (and the percentage responding correctly in $1980(n=16)$ and $2008(n=27)$.

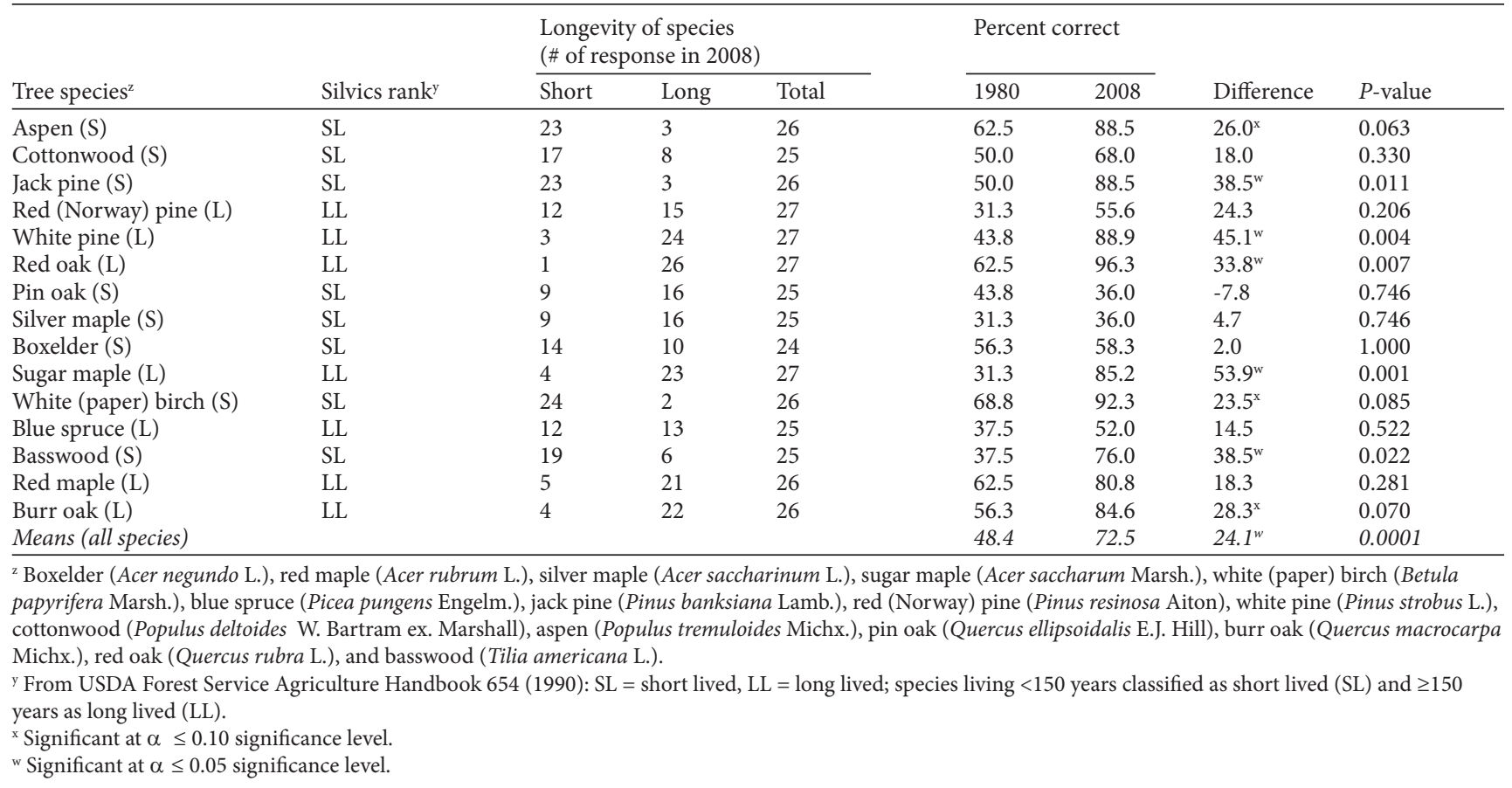

Table 5. Percent of builders rating a tree species for shade tolerance as either poor $(P)$ or good $(G)$ and the percentage responding correctly in $1980(n=16)$ and $2008(n=27)$.

\begin{tabular}{|c|c|c|c|c|c|c|c|c|}
\hline \multirow[b]{2}{*}{ Tree species ${ }^{z}$} & \multirow[b]{2}{*}{ Silvics rank ${ }^{y}$} & \multicolumn{3}{|c|}{$\begin{array}{l}\text { Tolerance of species } \\
\text { (\# of response in 2008) }\end{array}$} & \multicolumn{2}{|c|}{ Percent correct } & \multirow[b]{2}{*}{ Difference } & \multirow[b]{2}{*}{$P$-value } \\
\hline & & Poor & Good & Total & 1980 & 2008 & & \\
\hline Aspen (P) & VI & 17 & 6 & 23 & 37.5 & 73.9 & $36.4^{\mathrm{w}}$ & 0.046 \\
\hline Cottonwood (P) & VI & 12 & 9 & 21 & 31.3 & 57.1 & 25.8 & 0.185 \\
\hline Jack pine $(\mathrm{P})$ & IT & 12 & 9 & 21 & 31.3 & 57.1 & 25.8 & 0.185 \\
\hline Red (Norway) pine (P) & IT & 15 & 8 & 23 & 37.5 & 65.2 & 27.7 & 0.112 \\
\hline White pine $(G)$ & IN & 13 & 10 & 23 & 37.5 & 43.5 & 6.0 & 0.752 \\
\hline Red oak $(G)$ & IN & 16 & 7 & 23 & 50.0 & 30.4 & -19.6 & 0.318 \\
\hline Pin oak $(\mathrm{P})$ & IT & 15 & 7 & 22 & 31.3 & 68.2 & $36.9^{\mathrm{w}}$ & 0.047 \\
\hline Silver maple (G) & IN & 11 & 10 & 21 & 25.0 & 52.4 & 27.4 & 0.191 \\
\hline Boxelder $(G)$ & TO & 9 & 12 & 21 & 18.8 & 42.9 & $24.1^{\mathrm{w}}$ & 0.041 \\
\hline Sugar maple (G) & VT & 11 & 12 & 23 & 43.8 & 52.2 & 8.4 & 0.748 \\
\hline White (paper) birch (P) & IT & 13 & 9 & 22 & 37.5 & 59.1 & 21.6 & 0.325 \\
\hline Blue spruce $(\mathrm{G})$ & IN & 12 & 10 & 22 & 37.5 & 45.5 & 8.0 & 0.744 \\
\hline Basswood (G) & TO & 12 & 9 & 21 & 31.3 & 42.9 & 11.6 & 0.515 \\
\hline Red maple (G) & TO & 11 & 11 & 22 & 50.0 & 50.0 & 0.0 & 1.000 \\
\hline Burr oak (G) & IN & 8 & 13 & 21 & 18.8 & 61.9 & $43.1^{\mathrm{w}}$ & 0.018 \\
\hline Means (all species) & & & & & 34.6 & 53.5 & $18.9^{w}$ & 0.0001 \\
\hline
\end{tabular}

${ }^{\mathrm{z}}$ Boxelder (Acer negundo L.), red maple (Acer rubrum L.), silver maple (Acer saccharinum L.), sugar maple (Acer saccharum Marsh.), white (paper) birch (Betula papyrifera Marsh.), blue spruce (Picea pungens Engelm.), jack pine (Pinus banksiana Lamb.), red (Norway) pine (Pinus resinosa Aiton), white pine (Pinus strobus L.), cottonwood (Populus deltoides W. Bartram ex. Marshall), aspen (Populus tremuloides Michx.), pin oak (Quercus ellipsoidalis E.J. Hill), burr oak (Quercus macrocarpa Michx.), red oak (Quercus rubra L.), and basswood (Tilia americana L.).

${ }^{y}$ From USDA Forest Service Agriculture Handbook 654 (1990): VI = Very Intolerant, IT = Intolerant, IN = Intermediate, TO = Tolerant, VT = Very Tolerant; species with VI and IT ranking are considered poor tolerance $(\mathrm{P})$ and species with IN, TO, or VT ranking are considered good tolerance (G).

x Significant at $\alpha \leq 0.10$ significance level.

w Significant at $\alpha \leq 0.05$ significance level. 
important activities and had a median score of 4. Consulting tree professionals was the only activity with an index score below 3 (neutral score), and over $80 \%$ of builders considered this very unimportant (19\%), unimportant $(27 \%)$, or neutral $(35 \%)$. Builders were more neutral (median value $=3$ ) regarding moving the proposed house and road locations based on tree susceptibility to construction activities (3.15), inventorying tree size (3.15), incorporating tree protection zones (3.26), inventorying tree species (3.26), identifying tree care needs (3.27), creating tree protection zones based on species tolerance to construction (3.31), or creating tree protection zones based on the critical root zone (3.38).

\section{DISCUSSION}

After 28 years, many of the studied builder perceptions, knowledge, and activities did not change. The few that did change were mixed with the potential benefit toward minimizing damage to trees from construction. These findings are important, since the practices of builders can have profound impacts on the health and survival of trees during development (Hauer et al. 1994; Fite and Smiley 2008b; Fite and Smiley 2009; Koeser et al. 2013).

\section{Perceptions}

The results from this study found that building homes in wooded lots continued to be common in central Wisconsin, with all builders responding to this study doing such. An average of about half of the trees were removed from the lot, and no builder responded that the site was ever totally denuded of trees. In the study area, builders primarily construct custom homes (pers. observation). Developing several homes at a time on speculation (e.g., home built in anticipation of a buyer) was less common in the study area, even in subdivisions considered large for the area. This prevalence of custom homes may explain why about two-thirds of builders indicated they do not receive complaints at all from clients regarding trees. Clients who pay for custom-

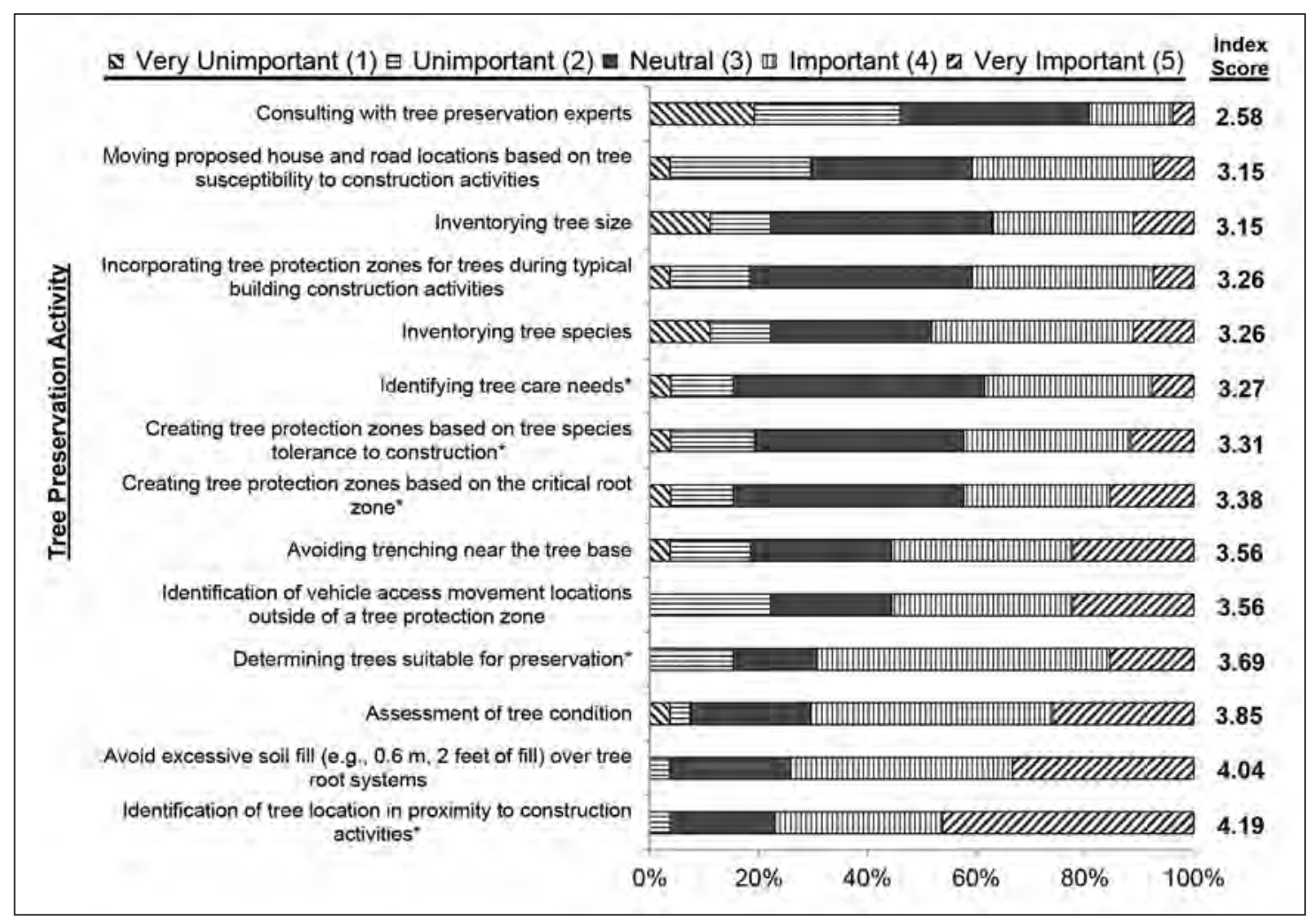

Figure 2. Rating by builders in central Wisconsin of tree preservation activities for their importance during building on wooded lots [ $n=27$, except questions noted with an asterisk (*) where $n=26$ ]. 
built homes putatively visit the site before and during construction to add their input, which conceivably results in few surprises.

Most builders gave no preference to the size of trees they remove, but those that did tended to leave large trees standing, which was consistent with the desire of the majority of homebuyers. Despot and Gerhold (2003) found that an overwhelming majority of builders agreed that clients will pay extra for large trees to be preserved on-site. Similarly, removing about half of the trees on the lot was consistent with homebuyers' overwhelming desire for a finished lot that was both partially landscaped and partially natural. These findings are also consistent with Schroeder and Green (1985) and Yang et al. (2009), who found large trees and moderately dense (park-like) environments are visually attractive and highly rated. The preference for what a site looks like did vary by the person's age, education level, occupation, and personal level of interest in a natural environment (Brush 2000; Bjerke et al. 2006; Nassauer et al. 2009; Miller et al. 2015).

\section{Knowledge}

The results confirm that most builders did not consult a tree preservation expert (78\%), such as an arborist or forester, and they ranked 'consulting with tree preservation experts' as the very least important activity when preserving trees on wooded lots (index 2.58). Similarly, Olsen et al. (2014) found that $77 \%$ of construction professionals in Alabama, U.S., seldom (41\%) or never (26\%) work with a certified arborist before beginning construction on a project with trees to be preserved. The remaining $33 \%$ seldom worked with certified arborists and no one said they always or almost always do such. The use of certified arborists to review construction plans for tree protection and preservation was also uncommon in the Alabama study, with $100 \%$ saying they sometimes (37\%), seldom (9\%), or never (54\%) consult with this credentialed expert. This exemplifies why it is so important that homeowners become educated and begin requesting proper tree preservation practices and the involvement of those that have the necessary skills and knowledge (Fite and Smiley 2008a). Olsen et al. (2014) found that the primary barrier to implementing tree preservation on a project was that clients do not request it, with over $90 \%$ sometimes (52\%) and seldom or never (41\%) requesting tree protection. If clients requested that proper tree preservation practices be followed, builders could presumably find a way to comply.

Many mechanisms exist to educate homeowners and builders through outreach programs, including local municipal foresters, extension personnel, university educators, professional organizations, non-profit groups, private companies, and others (Nichnadowicz 2007; Hauer and Johnson 2008; Miller et al. 2015). Builders themselves could develop knowledge of best management practices for construction practices in wooded environments, but interest in a workshop was limited. This could change if homeowners began requesting those practices more frequently, since builders are motivated by market demand (Tinker et al. 2006).

A regulation through local ordinance or state statute is another way to force adherence to tree preservation standards (Abbey 1998; Galvin et al. 2010; Miller et al. 2015). Woodland protection ordinances have become more common. Duerksen and Richman (1993) reported that 100 tree protection ordinances existed in the entire United States in the early 1980s. By the end of that decade, over 80 such ordinances existed in the state of California alone. Today, nearly $50 \%$ of communities $(n \approx 650)$ that responded to a national municipal tree management survey indicated they have an ordinance that details some level of tree preservation during development on public and/or private land (Hauer and Peterson 2015). Schmied and Pillman (2003) found 74\% of 34 contacted cities in Europe had tree protection legislation for public and/or private areas. Elmendorf et al. (2003) found in Pennsylvania, U.S., that most shade tree commission respondents had the attitude that tree preservation ordinances (81\%) and preserving trees in development (87\%) was important. In practice, however, approximately $20 \%$ had a tree preservation or landscape ordinance, and $20 \%$ practiced approaches to preserve trees in construction.

In this study area, no local ordinances or state laws regulate construction near trees. One possible reason for a lack of tree preservation regulations is that the study area has much residual forested area that has not been developed, and any visual impact of tree loss from either removal or later constructioninduced mortality is minimal. There is an example of one covenant from the study area that regu- 
lates tree removal and requires at least $25 \%$ of the lot trees be preserved or $25 \%$ of the lot be planted with trees (City of Stevens Point, undated).

Builders, however, perceive regulatory approaches as moderately effective with tree preservation compared to arborists and designers who viewed them as a useful part of promoting tree preservation (Despot and Gerhold 2003). Janse and Konijnendijk (2007) found that in order to develop effective public policy and regulatory approaches, decision making is best developed by a stepwise process that uses socially inclusive planning by first informing public constituents in an alluring way to determine public opinion and directly involving people in a fully participatory process. Regardless of whether local ordinances or state laws regulate trees during construction, the ANSI A300 Part 5 provides standards for developing specifications for managing trees and shrubs in development areas (Fite and Smiley 2008a; TCIA 2012). For example, the standard specifies an arborist or other qualified person should be involved with site assessments. An arborist should further be involved with the implementation of on-site recommendations during the construction phase. Thus, even without local regulations, a national standard provides a basis that qualified people (e.g., an arborist) should be involved with tree conservation and preservation objectives that involve trees during construction (Fite and Smiley 2008a). As found in this study in Wisconsin and in the study in Alabama by Olsen et al. (2014), this consultation occurs infrequently. Or the consultation occurs too late in the development process to prevent some construction damage to trees (Despot and Gerhold 2003).

When compared to the 1980 study, builder knowledge of soils increased. Despot and Gerhold (2003) found $58 \%$ of builders strongly agreed or agreed they knew enough about the effects of soil properties in tree survival and growth to adequately specify or use tree preservation methods. All builders in this study correctly arranged three soil textures according to air and water movement through the soil, an important concept for construction activities in general and for understanding trees' susceptibility to construction impacts. However, few could arrange soil textures according to susceptibility to compaction, which is also important in construction practices. The wording of these two arrangement-type ques- tions may have biased these results. The words "susceptibility to" were omitted in both studies and the respondents were asked to arrange soil textures "according to the degree of compaction." The importance of tree root growth and limitations imposed by negative soil changes (e.g., compaction, saturation, oxygen limitation) are well-reviewed by Day et al. (2010b). Compaction on construction sites, if not prevented, can increase soil bulk density levels to those that impede root growth and lead to tree death (Alberty et al. 1984; Randrup 1997; Scharenbroch et al. 2005; Tirado-Corbalá and Slater 2010).

Unlike questions concerning soils, knowledge of tree-understory relationships was relatively the same and reflects the interest of clients. Builders indicated that homebuyers express no preference for small trees to be left on-site, which could be interpreted by builders as 'no undergrowth.' Thirty percent of builders indicated that the removal of native undergrowth vegetation and leaf litter would actually be beneficial to tree health. It seems that undergrowth and leaf litter were generally ignored or removed as a nuisance by builders because clients usually express no preference for them.

Builders showed a significant increase in their understanding of the negative effects caused by heavy equipment and soil storage near the base of the tree. Preventing soil compaction can be done by either not using equipment in a tree protection zone or placing materials (e.g., mulch, gravel, plywood) over the root system to minimize compaction (Lichter and Lindsey 1994). Over half of builders in Pennsylvania said the use of wood chips was beneficial to reduce soil compaction, but only $0.1 \%$ actually used this practice (Despot and Gerhold 2003). This study likewise found few builders regularly (4\%) or occasionally (15\%) used mulch or boards. Nearly all builders in this study and over $80 \%$ in a study by Despot and Gerhold (2003) knew keeping fill outside the root area was best. Yet in both studies storage of fill within the root area up to the tree stem regularly occurred.

The percentage of builders responding that it was wise to treat root loss with compensatory crown pruning was $30 \%$, and statistically similar to the $50 \%$ in 1980 . The correct answer in 1980 was that compensatory pruning was a practice to counteract damage to tree root systems; however, the literature since that time has moved away from a clear con- 
sensus on this topic (Watson 1998; Watson et al. 2014b). Builder understanding of the structure of tree root systems was generally poor with only $11 \%$ believing that tree roots generally extend away laterally from the tree beyond the dripline, which could have dangerous implications for trees on construction sites. This knowledge was inconsistent with Day et al. (2010a), who found that tree roots can extend several times the height of a tree away from the stem. Even though tree height is commonly used to provide a lateral extent of tree root systems, tree diameter appears to be a better predictor (Day et al. 2010a). There was a significant decrease in the number of builders believing that application of nitrogen was helpful to tree recovery from root loss. Fertilization during and at least one year after construction should be modest at most, unless a nutrient deficiency exists (Harris et al. 2004).

\section{Activities}

Despite some minor improvement in their knowledge, builders in this study still commonly engaged in activities potentially detrimental to the successful preservation of trees on construction sites, such as storing building materials near the base of trees, using heavy equipment near the base of trees, placing sidewalks within $3 \mathrm{~m}$ of trees, and trenching for utilities. Other detrimental activities, such as bringing in fill soil to raise the grade of a site and storing soil near the base of trees, have both increased significantly since 1980 . This was all despite scoring very highly on questions regarding soils, making improvements since 1980 on questions regarding damage to root systems, and rating the avoidance of excessive fill soil over tree root systems as the second most important tree preservation decision (index 4.04).

Raising the grade of a site could be done for a variety of reasons, such as to facilitate a walkout basement. It could also be done to facilitate raising the grade above a seasonal flooding issue. In the study area, much of the development occurs in welldrained outwash sand plains and moraines, which were both artifacts of glacial activity that ended approximately 10,000 years ago (Clayton et al. 2006). The western part of the study area has older soils that were untouched by the last glacial period, have greater clay content, and drain more poorly, which can result in seasonal flooding. In this situation, raising the grade during development could account for a change in the builder response to this question. However, development in the well-drained sites was as common in this study as it was in 1980.

Excavation within the critical root zone can lead to declining and dead trees (Fite and Smiley 2008a). Very few builders (7\%) in 2008 reported placing foundations within $3 \mathrm{~m}$ of trees. In 1980 , over $60 \%$ did such. This significant reduction $(P<0.000)$ with few builders excavating soil within $3 \mathrm{~m}$ of trees could be the result of selective placement of buildings or the preemptive removal of trees deemed too close for survival. This result might also apply to placement of driveways and sidewalks. But it was not known if this was because driveways and sidewalks are moved during the planning stage or if the trees were simply removed more often. Smiley (2008) found that trenching cuts made closer than three times the stem diameter away from willow oak (Quercus phellos L.) took less force for tree failure. Thus, the recommendation with trenching is to stay at least three times the diameter or more away from the stem. Thus, if builders from this study stayed at least $3 \mathrm{~m}$ away with root severing, then assuming a similar outcome as with willow oak, tree stability would likely be insignificant for trees up to $100 \mathrm{~cm}$ in diameter. If root disruption does occur on one side of the tree and a distance of $3 \mathrm{~m}$ or more away is maintained, an effect of greater tree death or reduced tree health was less likely (Hauer et al. 1994; Koeser et al. 2014).

It is possible that the lack of painting of wounds of oak trees by over $60 \%$ of the builders is an artifact of messages since the 1970s and 1980s that say painting tree wounds is not beneficial and can exacerbate tree decay (Shigo and Shortle 1983). Applying a wound dressing and proper pruning using the cut promoted by Shigo reduced the chance of oak wilt when a tree is pruned or wounded (Camilli et al. 2007). In the Midwest, many educational approaches (e.g., billboards, public service announcements, brochures, newspaper articles, workshops) exist to educate professionals and laypeople about oak wilt management (Miller et al. 2015). Avoiding wounding of oak trees, and if wounding occurs covering the wound immediately (paint is often suggested), are two main points.

Builders are either not motivated to change their activities, have little financial incentive, and/or lack training on alternative construction methods conducive to the effective preservation of trees. Despot 
and Gerhold (2003) found the Building with Trees seminar, hosted by The Arbor Day Foundation, to be effective in increasing knowledge of construction practices in wooded areas. University extension agencies and state departments of forestry have produced comprehensive guides available for free, such as those in Minnesota (Johnson 1999), Pennsylvania (Elmendorf 2005), Oregon (Ries et al. 2009), and other locations. Theinformation and training was and still is available if builders are motivated to pursue it.

\section{CONCLUSIONS}

Many practices that builders were using when constructing homes on wooded sites in 1980 have not changed in the recent study. This stagnation in builder practices is in stark contrast to the proliferation in understanding of the impacts of construction activities near trees in the arboriculture field. Although efforts to educate builders have been made (Johnson 1999; Elmendorf 2005; Ries et al. 2009), the knowledge isn't being applied. As the potential negative impacts to trees due to construction activities are huge, the weight of this issue is critical.

Builders continued to trench and place driveways near trees. They were much less likely to place foundations near trees, however, placing fill near trees and raising the grade became more common. Interestingly, most builders knew placing fill near trees was improper, yet they were more likely to do so today. Thus, many builders apparently understand some basic tree biology, yet fail to act upon the best management practice.

Builders' poor knowledge of tree preservation practices remains constant, and they have limited interest in receiving training on the topic. However, as evidenced through the revolution of energy efficiency in new homes over the last 20 to 30 years, builders actually are quite adaptable in their skills and knowledge and will modify practices if the marketplace or buyers ask for such (Tinker et al. 2006). Further, working proactively with builders and developers before and during construction can help mitigate or prevent damage to trees from development (Ames and Dewald 2003).

Builders are motivated by profit and market demand (Vigmostad 2003; Tinker et al. 2006). Custom-built homes are common in this area, which is more likely to ensure a profit in all reasonable circumstances. This leaves market demand (client request) as the primary influence on builders' actions. Vigmostad (2003) states, "Developers do not want to do what is unpopular and have shown that they will respond to changes in public values." Builders in Michigan understood homebuyer preference for different forms of ecological versus conventional designs (Westbrook 2010). Their perception of the profitability was a barrier for deviating from conventional practice especially in low to mid-priced markets (Westbrook 2010). If homebuyers were educated on tree preservation and requested that an arborist or other professional trained in tree preservation were included in the design and construction process, the builder would almost certainly comply. Homeowner request or builder use of tree preservation experts was limited, even though national standards specify they should be used in tree preservation projects. Thus, either there is a lack of knowledge or use of standards, such as the ANSI A300, or tree preservation is not an objective during development.

Builders themselves may also then be motivated to pursue training, which could result in a boon for tree preservation by filling the current gap in incentive. This gap is characterized by builders who have hardly changed their practices or advanced their knowledge of tree preservation over this 28-year span, and a total lack of regulation in the study area. Education and regulation can be thought of as complementary means to achieving a shared goal, and in this case, regulation isn't present, thus leaving education as the only option. The best hope for motivating builders to pursue education may be market demand through consumer education.

Demand from educated consumers, and in some states, changes to building code, has resulted in builders learning and adopting the new skills required to use new building materials and practices designed to increase home energy efficiency. A similar renaissance could occur in the practices and knowledge of builders, if proper tree preservation became the new convention during home construction or if tree preservation became part of local, state, or national building code. The greatest impact on tree preservation during home construction in wooded lots may be through the education of the public on the necessity to involve tree preservation professionals during the planning, construction, and post-construction stages of home building. 
Acknowledgments. The authors thank three anonymous reviewers for their suggestions with the improvement of this paper. We are also grateful for the financial support from the Student Research Fund (now Undergraduate Research and Creative Activity Grant) from the University of Wisconsin-Stevens Point (UWSP) Office of Research and Sponsored Projects. We also thank the UWSP College of Natural Resources for Financial Support and sponsorship with the publication of this paper.

\section{LITERATURE CITED}

Abbey, B. 1998. U.S. landscape ordinances: an annotated reference handbook. John Wiley \& Sons, New York, New York, U.S. 438 pp.

Alberty, C.A., H.M. Pellett, and D.H. Taylor. 1984. Characterization of soil compaction at construction sites and woody plant response. Journal of Environmental Horticulture 2(2):48-53.

Ames, B., and S. Dewald. 2003. Working proactively with developers to preserve urban trees. Cities 20(2):95-100.

Anderson, L.M., and J. Barrows-Broaddus. 1989. Inexpensive ways to improve home-builders tree survival. Journal of Arboriculture 15:13-16.

Bjerke, T., T. Østdahl, C. Thrane, and E. Strumse. 2006. Vegetation density of urban parks and perceived appropriateness for recreation. Urban Forestry \& Urban Greening 5(1):35-44.

Bowman, T., and J. Thompson. 2009. Barriers to implementation of low-impact and conservation subdivision design: Developer perceptions and resident demand. Landscape and Urban Planning 92(2):96-105.

Brush, R., R.E. Chenoweth, and T. Barman. 2000. Group differences in the enjoyability of driving through rural landscapes. Landscape and Urban Planning 47(1):39-45.

Camilli K., D.N. Appel, and W.T. Watson. 2007. Studies on pruning cuts and wound dressings for oak wilt control. Arboriculture \& Urban Forestry 33(2):132-139.

City of Stevens Point. Undated. Restrictive covenants Whitetail \& Whitetail Trail Subdivisions. Accessed 05 January 2016. <www. ci.stevens-point.wi.us/index.aspx?NID=137>

Clayton L., J.W. Attig, D.M. Mickelson, M.D. Johnson, and K.M. Syverson. 2006. Glaciation of Wisconsin. Educational Series 36. Wisconsin Geological and Natural History Survey. Madison, Wisconsin, U.S. 4 pp.

Day, S.D., and N.L. Bassuk. 1994. A review of the effects of soil compaction and amelioration treatments on landscape trees. Journal of Arboriculture 20(1):9-17.

Day, S.D., P.E. Wiseman, S.B. Dickinson, and J.R. Harris. 2010a. Contemporary concepts of root system architecture of urban trees. Arboriculture \& Urban Forestry 36(4):149-159.

Day, S.D., P.E. Wiseman, S.B. Dickinson, and J.R. Harris. 2010b. Tree root ecology in the urban environment and implications for a sustainable rhizosphere. Arboriculture \& Urban Forestry 36(5):193-205.

Despot, D., and H. Gerhold. 2003. Preserving trees in construction projects: Identifying incentives and barriers. Journal of Arboriculture 29(5):267-280.

Dillman, D.A. 2007. Mail and internet surveys: The Tailored Design Method. John Wiley \& Sons, New York, New York, U.S. 523 pp.

Duerksen, C.J., and S. Richman. 1993. Tree Conservation Ordinances (Rep. No. 446). Chicago: American Planning Association.
Elmendorf, W.F., V.J. Cotrone, and J.T. Mullen. 2003. Trends in urban forestry practices, programs, and sustainability: Contrasting a Pennsylvania, U.S., study. Journal of Arboriculture 29(4):237-248.

Elmendorf, W.F. 2005. A Guide to Preserving Trees in Development Projects. Penn State, College of Agricultural Sciences, Cooperative Extension, UH122. University Park, Pennsylvania, U.S. 27 pp.

Ernster, T. 2015. Personal communication, City Forester, Stevens Point, Wisconsin, U.S. 30 April 2015.

Fite, K., and E.T. Smiley. 2008a. Best Management Practices: Managing Trees During Construction. International Society of Arboriculture, Champaign, Illinois, U.S. 35 pp.

Fite, K., and E.T. Smiley. 2008b. Managing trees during construction: Part one. Arborist News 17(6):12-17.

Fite, K., and E.T. Smiley. 2009. Managing trees during construction: Part two. Arborist News 18(1):12-17.

Galvin, M.F., B. Wilson, and M. Honeczy. 2000. Maryland's Forest Conservation Act: A process for urban greenspace protection during the development process. Journal of Arboriculture 26(5):275-280.

Gilbert, O.L. 1996. Retaining trees on construction sites. Arboricultural Journal 20:39-45.

GraphPad. 2015. Fisher's exact test $2 \times 2$ contingency table. Accessed 05 January 2016. <http://graphpad.com/quickcalcs/contingency1./>

Haines, A.L., T.T. Kennedy, and D.L. McFarlane. 2011. Parcelization: Forest change agent in northern Wisconsin. Journal of Forestry 109(8):101-108.

Haines A.L., and D.M. McFarlane. 2012. Factors Influencing parcelization in amenity-rich rural areas. Journal of Planning Education and Research 32(1):81-90.

Harris, R.W., J.R. Clark, and N.P. Matheny. 2004. Arboriculture: Integrated Management of Landscape Trees, Shrubs, and Vines, fourth edition. Prentice Hall, Upper Saddle River, New Jersey, U.S. $578 \mathrm{pp}$

Hauer, R.J., and G.R. Johnson. 2008. State urban and community forestry program funding, technical assistance, and financial assistance within the 50 United States. Arboriculture \& Urban Forestry 34(5):280-289.

Hauer, R.J., R.W. Miller, and D.M. Ouimet. 1994. Street tree decline and construction damage. Journal of Arboriculture 20(2):94-97.

Hauer, R.J., and W. Peterson. 2015. Municipal Forestry, Tree Activities, and Management in the United States. A 2014 Urban \& Community Forestry Census of the United States. Conference Proceedings of the International Society of Arboriculture 91st Annual Conference \& Trade Show. Orlando, FL. 09-12 August 2015. Accessed 05 January 2016. <www.isa-arbor.com/events/ schedule/item.aspx?EventID=167\&SubEventID $=118>$

Hoff, M. (Ed.). 1999. Conserving Wooded Areas in Developing Communities: Best Management Practices in Minnesota. Minnesota Department of Natural Resources, Division of Forestry. Saint Paul, Minnesota, U.S. 113 pp.

Janse, G., and C.C. Konijnendijk. 2007. Communication between science, policy, and citizens in public participation in urban forestry: Experiences from the neighbourwoods project. Urban Forestry \& Urban Greening 6(1):23-40.

Johnson, G.R. 1999. Protecting Trees From Construction Damage: A Homeowner's Guide. University of Minnesota Extension Service. FO-6135-S, rev., 1999. 15 pp. 
Koeser, A., R. Hauer, K. Norris. and R. Krouse. 2013. Factors influencing long-term street tree survival in Milwaukee, WI, USA. Urban Forestry \& Urban Greening 12(4):562-568.

Konijnendijk, C.C. 2008. The Forest and the City: The Cultural Landscape of Urban Woodland. Springer. 245 pp.

Lichter J.M., and P.A. Lindsey. 1994. Prevention of soil compaction during site construction. Journal of Arboriculture 20(4):205-209.

Lowery, R. 2015. Two independent proportions module. Accessed 05 January 2016. <http://vassarstats.net/propdiff_ind.html>

Matheny, N., and J.R. Clark. 1998. Trees And Development: A Technical Guide to Preservation of Trees During Land Development. International Society of Arboriculture, Champaign, Illinois, U.S. 183 pp.

Miller, R.W., R.J. Hauer, L.P. Werner. 2015. Urban Forestry: Planning and Managing Urban Greenspaces, third edition. Waveland Press, Long Grove, Illinois, U.S. 560 pp.

Nassauer, J.I., Z. Wang, and E. Dayrell. 2009. What will the neighbors think? Cultural norms and ecological design. Landscape and Urban Planning 92:282-292.

Nichnadowicz, J. 2007. Community Involvement in Urban Forestry Programs. pp. 121-135. In: J.E. Kuser (Ed.). Handbook of Urban and Community Forestry in the Northeast. Kluwer Academic/ Plenum, New York City, New York, U.S.

O'Callaghan, D., and M. Lawson. 1995. Trees and development conflicts: The importance of advance planning and site control in tree preservation Plans. pp.143-155. In: G.W. Watson and D. Neely (Eds.). Trees and building sites: Proceedings of an International Workshop on Trees and Buildings, Lisle, Illinois, U.S., 31 May - 02 June 1995. International Society of Arboriculture, Savoy, Illinois, U.S.

Olsen, D.A., J.M. Taylor, and E. Brodbeck. 2014. Tree preservation methods and barriers, perspectives of the design and construction community. In: T. Sulbaran (Ed.). 50th ASC Annual International Conference Proceedings. Blacksburg, Virginia, U.S. 26-28 March 2014. Accessed 05 January 2016. <http://ascpro0. ascweb.org/archives/cd/2014/paper/CPGT218002014.pdf>

Ott, R.L., and M. Longnecker. 2010. An Introduction to Statistical Methods and Data Analysis, sixth edition. Brooks/Cole., Belmont, California, U.S. 1296 pp.

Randrup, T.B. 1997. Soil compaction on construction sites. Journal of Arboriculture 23(5):207-210.

Ries, P.D., D. Godwin, S. Foster, M. McNaughton, M. Cahill, T. Fitzgerald, J. Freed, S. Johns, and L. Mead. 2009. Tree Protection on Construction and Development Sites: A Best Management Practices Guidebook for the Pacific Northwest. Extension Service, Oregon State University, Corvallis, Oregon, U.S. 20 pp.

Ryan, R.L. 2006. Comparing attitudes of local residents, planners, and developers about preserving rural character in New England. Landscape and Urban Planning 75(1-2):5-22.

Scharenbroch, B.C., J.E. Lloyd, and J.L. Johnson-Maynard. 2005. Distinguishing urban soils with physical, chemical, and biological properties. Pedobiologia 49(4):283-296.

Schmied, A., and W. Pillmann. 2003. Tree protection legislation in European cities. Urban Forestry \& Urban Greening 2(2):115-124.

Schroeder, H.W., and T.L. Green. 1985. Public preference for tree density in municipal parks. Journal of Arboriculture 11(9):272-277.
Sevelka, T. 2004. Subdivision development: Risk, profit, and developer surveys. The Appraisal Journal 72(4):242-252.

Shigo, A.L., and W.C. Shortle. 1983. Wound dressings: Results of studies over 13 years. Journal of Arboriculture 9(12):317-329.

Smiley, E.T. 2008. Root pruning and stability of young willow oak. Arboriculture and Urban Forestry 34(2):123-128.

TCIA. 2012. ANSI A300 (Part 5): American National Standards for Tree Care Operations-Tree, Shrub, and Other Woody Plant Maintenance: Standard Practices (Management of Trees and Shrubs During Site Planning, Site Development, and Construction). Tree Care Industry of America. Manchester, New Hampshire, U.S. 21 pp.

Tinker, A., U. Kreuter, R. Burt, and S. Bame. 2006. Green construction: Contactor motivation and trends in Austin, Texas. Journal of Green Building 1(2):118-134.

Tirado-Corbalá, R., and B.K. Slater. 2010. Soil compaction effects on the establishment of three tropical tree species. Arboriculture \& Urban Forestry 36(4):164-170.

U.S. Census Bureau. 2010. State \& County QuickFacts. Accessed 05 January 2016. <http://quickfacts.census.gov/qfd/ states/55/55097.html>

Vander Weit, W.J. 1984. The Wooded Lot: Homeowner and Builder Knowledge and Perceptions in Selected Central Wisconsin Subdivisions. M.S. Thesis. University of Wisconsin-Stevens Point. $71 \mathrm{pp}$

Vander Weit, W.J., and R.W. Miller. 1986. The wooded lot: Homeowner and builder knowledge and perception. Journal of Arboriculture 12:129-134.

Vigmostad, K. 2003. Michigan Real Estate Developer Perspective on Development, Sustainability, and Nature: An Autoethnography. Doctoral dissertation, Michigan State University, Lansing, Michigan, U.S.

Watson, G.W. 1998. Tree growth after trenching and compensatory crown pruning. Journal of Arboriculture 24(1):47-53.

Watson, G.W., A.M. Hewitt, M. Custic, and M. Lo. 2014a. The management of tree root systems in urban and suburban settings. I. A review of soil influence on root growth. Arboriculture \& Urban Forestry 40(4):193-217.

Watson, G.W., A.M. Hewitt, M. Custic, and M. Lo. 2014b. The management of tree root systems in urban and suburban settings. II. A review of strategies to mitigate human impacts. Arboriculture \& Urban Forestry 40(5):249-271.

Westbrook, S.E. 2010. Residential Developers' Perspectives of Ecological Alternatives for Exurban and Suburban Development. M.L.A. Thesis, University of Michigan, Ann Arbor, Michigan, U.S. 75 pp.

Yang, J., L. Zhao, J. McBride, and P. Gong. 2009. Can you see green? Assessing the visibility of urban forests in cities. Landscape and Urban Planning 91(2):97-104. 


\author{
Keith O'Herrin (corresponding author) \\ Ph.D. Candidate - Urban Forestry \\ Department of Forest Resources and Environmental \\ Conservation \\ Virginia Tech \\ Cheatham Hall \\ 310 W Campus Drive \\ Blacksburg, Virginia 24061, U.S. \\ koherrin@vt.edu
}

Richard J. Hauer

Professor

Urban Forestry

University of Wisconsin-Stevens Point

Stevens Point, Wisconsin, U.S.

William J. Vander Weit

Retired City Forester

Champaign, Illinois, U.S.

\author{
Robert W. Miller \\ Emeritus Professor \\ Urban Forestry \\ University of Wisconsin-Stevens Point \\ Stevens Point, Wisconsin, U.S.
}

Résumé. La construction de nouvelles maisons sur des terrains boisés est courante dans le Midwest supérieur, aux États-Unis. Les arbres existants sont souvent conservés durant la construction pour éventuellement faire partie du futur aménagement paysager. Une étude réalisée en 1980 a permis de constater que les entrepreneurs en construction du comté de Portage dans le Wisconsin, aux ÉtatsUnis, avaient généralement une mauvaise compréhension des impacts que les activités de construction avaient sur la santé des arbres qu'ils souhaitaient conserver. Les chercheurs ont reproduit une recherche similaire, 27 années plus tard, lors d'une étude auprès d'entrepreneurs en construction de maisons dans la même région pour voir si leurs connaissances sur la préservation des arbres et leurs pratiques en construction de maisons avaient changé durant cette période. Les résultats indiquent que peu d'activités de construction ont changé de manière significative, démontrant ainsi que, dans l'ensemble, peu de changements ont été constatés afin d'améliorer la préservation des arbres lors des travaux. Même si les entrepreneurs en construction ont considérablement amélioré leurs connaissances sur les effets négatifs que l'accumulation du sol de remblai au-dessus du système racinaire a sur la préservation des arbres, ils ont également augmenté de manière significative l'utilisation de cette même pratique. Les entrepreneurs en construction ne consultent presque jamais un expert en conservation des arbres et considèrent qu'il s'agit d'un geste de peu d'importance lorsqu'il est nécessaire de prendre des décisions pour la préservation d'arbres. L'intérêt pour des ateliers de formation sur la préservation des arbres était limité. Sans la pression des exigences des consommateurs ou l'obligation réglementaire, les entrepreneurs en construction n'amélioreront probablement pas leurs connaissances sur la préservation des arbres, ni ne modifieront leurs pratiques de construction, ni n'intégreront d'experts en conservation dans leur processus de travail.

Zusammenfassung. Im oberen Mittelwesten der Vereinigten Staaten ist es üblich, neue Häuser auf bewaldeten Grundstücken zu bauen. Existierende Bäume werden oft während der Bauphase dahinter belassen, um später ein Teil der künftigen Anlage zu werden. Eine in 1980 durchgeführte Studie fand heraus, das Hausei- gentümer in Portage County, Wisconsin, U.S. allgemein ein geringes Verständnis dafür haben, wie die Bauarbeiten die Gesundheit derjenigen Bäume, die später erhalten bleiben sollen, beeinflussen. Die Forscher wiederholten die Studie 27 Jahre später mit einer Umfrage bei Hauseigentümern in derselben Region um zu sehen, ob sich das Wissen um die Baumgesundheit und die Durchführung der Bauarbeiten über den Zeitraum verändert haben. Die Ergebnisse zeigen, dass nur einige wenige Bautechniken sich signifikant verändert haben und dass sich ansonsten nur wenig verändert hat um die Erhaltung der Bäume verbessern. Trotzdem die Bauherren ihr Wissen über die negativen Einflüsse von Übererdung von Baumwurzeln auf die Baumerhaltung vergrößert haben, wird die Technik aber dennoch vermehrt von ihnen. eingesetzt. Bauherren konsultierten fast nie Baumexperten und dachten, das wäre die am wenigsten wichtige Entscheidung, wenn sie Entscheidungen zur Baumerhaltung fällen müssten. Das Interesse an einem Workshop zur Baumerhaltung war begrenzt. Ohne den Druck von Konsumentenanforderungen oder Bestimmungen werden Bauherren wahrscheinlich nie ihre Kenntnisse zur Baumerhaltung verbessern, ihre Bauaktivitäten ändern oder einen Experten in irgendeiner Bauphase hinzuziehen.

Resumen. La construcción de nuevas viviendas en lotes boscosos es común en el Medio Oeste, Estados Unidos. Los árboles existentes a menudo se quedan durante la construcción para convertirse en parte del paisaje futuro. Un estudio realizado en 1980 encontró que los constructores de casas en el Condado de Portage, Wisconsin, EE.UU. generalmente tenían un mal entendimiento de cómo las actividades de construcción podrían afectar la salud de los árboles destinados a ser conservados. Los investigadores replicaron el estudio 27 años después mediante la inspección de los proyectos de los constructores de viviendas en la misma región para ver cómo sus conocimientos de conservación de los árboles y el uso de las actividades de construcción han cambiado durante ese tiempo. Los resultados indican que algunas actividades de construcción cambiaron significativamente, pero poco han cambiado en general para mejorar la conservación de los árboles. A pesar que los constructores mejoraron significativamente su conocimiento de los efectos negativos del almacenamiento de tierra de relleno sobre las raíces, aumentaron significativamente el uso de esa misma actividad. Los constructores casi nunca consultaron a un experto en conservación de los árboles y si pensaban hacerlo fue la actividad menos importante a la hora de tomar decisiones de preservación del árbol. El interés en un taller de capacitación en conservación de los árboles fue limitado. A menos de estar presionados por la regulación o la demanda de los consumidores, los constructores probablemente no mejoren sus conocimientos de preservación de los árboles, ni cambien sus actividades de construcción, o incluyan a expertos de árboles en todo el proceso. 